\title{
DOCUMENTATION OF INDIGENOUS KNOWLEDGE ON PRODUCTION AND POST-HARVEST MANAGEMENT OF SWEET POTATO IN THE BICOL REGION, PHILIPPINES
}

\author{
Glenton O. Guiriba \\ Department of Sociology, College of Social Sciences and Philosophy, Bicol University, Rizal \\ St. Sagpon, Daraga, Albay, 4501, Philippines. \\ E-mail: guiribaglenton@yahoo.com \\ Citation: Guiriba, G.O. 2019. Documentation of Indigenous Knowledge on Production and Post- \\ Harvest Management of Sweet Potato in the Bicol Region, Philippines. J. Asian Rur. Stud. \\ 3(1): 93-108
}

\begin{abstract}
Sweet potato (locally known as kamote) is a major staple food of people in the Bicol Region who live in the upland areas. They have been growing this crop for so many years, providing some form of food security and income to their households. They have also developed sustainable farming system using indigenous knowledge which they have learned from their ancestors. With increasing attention being given to the sustainable farming system, there is a need to look into the indigenous knowledge and practices of the sweet potato farmers in the Bicol Region, Philippines had adopted through the years in the cultivation, production, and post-harvest management of sweet potato. Hence, his paper aimed to document the various indigenous production and post-harvest practices of the sweet potato farmers; evaluate the cultural, social, economic and environmental aspects/dimensions of these indigenous knowledge; discover the gender division of labor in the sweet potato cultivation, production and post-harvest management; and discover the science behind the indigenous knowledge. The study made used of varied social research methods such as sample survey, key-informants interview, focus group discussions and field observations. This study has proven that indigenous knowledge and practices to the sweet potato farmers cannot be underestimated in terms of enhancing the household and community food production and food security particularly in the upland rural areas of the Bicol Region. The indigenous knowledge of the people is very effective in meeting their food requirements, and effective in areas of land preparation, soil fertility enrichment, planting, pests management and weeding, harvesting and post-harvest management.
\end{abstract}

Keywords: Indigenous knowledge; Sweet potato; Production; Post Harvest Management

\section{Introduction}

Playfully termed as "the musical fruit" meriting its own soundtrack in the Filipino culture, sweet potato (Ipomoea Batatas L.) is one of the most well-known and extensively cultivated root crops in the country---farming of this crop requires minimal maintenance and production cost is relatively cheap. Mostly grown in warm countries throughout the year, the leaves, tops, and root crops of kamote (sweet potato) are largely utilized as either food or feed. The heart-shaped kamote leaves are used as vegetables; kamote flesh (edible root) with white, purple, brown, or red skin are utilized mainly as food---even as staple food in Northern Mindanao and numerous other countries. It is a 
good source of carbohydrates, carotene, and polyphenolic antioxidants as well as an excellent source of vitamins A-C, calcium, iron, and phosphorous. Its leaves known as "talbos ng kamote" (kamote tops) is believed to lessen cholesterol and blood sugar levels; and may also be used for treatment of constipation and stomach stress. The nutritional and industrial (utilized in starch production) uses of kamote outweigh its disapproving folkloric image.

In the Philippines, kamote is cultivated as a basic staple food and as a special delicacy known as kamote chips. Largely a mainstay on the merienda table as a fried dish (kamote cue and kamote fries), production of sweet potato is focused mainly in the Bicol, Eastern Visayas and Central Visayas Regions. Although the industrial use of kamote in the Philippines is considerably superceded by its neighbors from China, Korea, and Vietnam where it is being utilized in the manufacture of chemical products such as, paper, paint, and ink, kamote as ingredient in food products such as catsup, jam, soy sauce, jellies and other bakery and non-bakery products (starch and flour) is increasing in popularity in the country. To date, recipes with sweet potato as ingredient include sweet potato catsup, and sweet potato hotcake as cited in the Sweet Potato Commodity Profile of the Bureau of Plant Industry.

Under the Philippine Food Staples Self-sufficiency Roadmap (FSSR) 2011-2016 that aims to achieve rice self-sufficiency by 2013 in the country, sweet potato plays a major role in the realization of this goal. Strategies to solve the food scarcity issue in the country by managing rice consumption include increasing food staple supply by 3.5 percent annually and making these crops affordable and available to everyone. Apart from sweet potato, white corn and cassava are among the promoted food staple crops that will help achieve this goal.

Due to its unique geographic location and physical environment, the Bicol Region is highly vulnerable to typhoons, floods, and droughts. On the average, the Bicol Region experiences 20 typhoons and tropical storms annually. Aside from typhoons and tropical storms, the Region also experiences high annual and seasonal variability because of diverse terrains with high mountains and volcanic landforms and extensive valleys interspersed with rivers and lakes. Moreover, the seasonal variations in weather, especially of rainfall, results to variations in production and seasonal price fluctuations that significantly affect the income of the farmers. Hence, there is a need to develop climate-responsive agriculture management approaches to improve the income of the locals and enhance their quality of life.

Sweet potato is one commodity which is tolerant to adverse climatic impacts. Planting sweet potato has several advantages within the context of Philippine cropping systems. It produces food for a relatively short period of time. It gives reliable yields in sub-optimal growth conditions. It requires lower labor inputs than other staples which is appropriate for vulnerable households. It serves as an alternative food source for urban populations especially those facing increasing prices of cereals. It provides potential options to reduce vitamin A deficiency.

At present, the Philippine Root Crop Research and Training Center (Phil Root Crops) in cooperation with the Philippine Council for Agriculture, Forestry and Natural Resources Research and Development (PCARRD) is implementing a program called "Enhancing Research Utilization for Sweet Potato Livelihood Development in DisasterProne Communities". The program aims to provide farmers access to high-yielding 
varieties, supply of high quality planting materials, for pests and diseases, and low soil fertility, and strengthen the link between technology sources and markets.

The program has already produced a number of significant Research and Development (R\&D) findings but there are also a number of problems and challenges that should be to be addressed to improve sweet potato production in the Region and respond to emerging opportunities relative to the processing of the commodity to higher-value products. Initial results showed low yield of varieties planted in the project sites due to gall mites infestation and long dry spell. Sweet potato weevil is also a potential pest problem of the commodity that could affect its shelf-life. Developing a viable sweet potato industry in the region would, therefore, need some Science and Technology (S\&T) interventions to address these pest problems.

Sweet potato declined quickly after harvest if they are not properly prepared for storage. The tubers tend to sprout or rot, depending on the quality of the sweet potato and how they are stored. There is a need, therefore, to determine the most appropriate storage for sweet potato tubers. Much will be lost to post-harvest problems even if sweet potato production is increased. If this problem will not be addressed.

At the moment, post-harvest processing and value-adding activities for sweet potato are mostly concentrated on the tubers. The tuber is made into flour from which other high-value products are manufactured such as noodles, snack foods, and the like. It is also being made into chips either for human consumption or animal feeds while efforts are now underway to manufacture wine from sweet potato tubers. The leaves and the vines of sweet potato have a good potential for post-harvest processing and valueadding activities. Swine raisers in rural barangays use them as feeds for animals while the young leaves or "camote tops" are nutritious for human consumption. Mature vines may also be used for handicraft-making either as the main raw material or for decorative purpose.

With increasing attention being given to the sustainable farming system, there is a need to look into the indigenous knowledge which sweet potato farmers in the Bicol Region had adopted through the years in the production and post-harvest management of sweet potato. Thus, this undertaking aimed to: (a) document the various indigenous production and postharvest practices of the sweet potato farmers; (b) evaluate the cultural, social, economic, and environmental aspects/dimensions of these indigenous knowledge; (c)discover the gender division of labor in the sweet potato cultivation, production and post-harvest management; and (d) discover the science behind their indigenous knowledge.

Specifically, this paper looked into the socio-demographic profile of the sweet potato farmers; their knowledge and practices in planting sweet potato; guides for land preparation and maintenance of soil fertility; sources of planting materials and planting techniques; common problems experienced and coping mechanisms adopted by the sweet potato farmers; post-harvest management of sweet potato; the gender division in sweet potato farming; and the science behind their indigenous knowledge.

\section{Scientific Basis/Theoretical Framework}

The Bicol Region is one of the most disaster-prone areas in the Philippines. Due to its unique geographic location and physical environment, it is highly vulnerable to 
typhoons, floods and droughts. The Region experiences an average of 20 typhoons and tropical storms annually that usually result to landslides, flashfloods, widespread flooding and together with strong winds, cause destruction and damage to homes, public infrastructures, and agriculture. The Region also experiences seasonal variations in weather, especially rainfall, resulting to variations in production and seasonal price fluctuations that significantly affect the income of the farmers.

Agriculture is the main source of the region's economy in which close to fifty percent $(50 \%)$ of the workforce are dependent for their livelihood and subsistence. It also contributes almost one-third of the region's economic output. The region's agricultural output, however, does not match with its productivity potential because of natural disasters. Climate change is expected to directly affect the Region's agricultural productivity given its vulnerability to climate-related hazards. This implies the need to come up with adaptation measures in the agriculture sector to make it more resilient to the occurrence of climate-related natural disasters.

According to a World Bank report, adaptation to climate impacts in the agriculture sector is not a new phenomenon (Kurukulasunya and Rosental, 2003). The report argued that natural and socio-economic systems have continuously been adapted autonomously, or in accordance to a plan, to a changing environment throughout history. However, the right mix of adaptations have the potential to significantly reduce or enhance the magnitude of potential adverse or beneficial impacts on agricultural productivity. The agricultural sectors is especially adaptable given the technological, resources, and management changes that can be undertaken relatively quickly (Mendeisohn, 2001). While adaptation options in agriculture are numerous, they must be site- and sector-specific and should reflect numerous decision rules. Schneider and others (2000), for instance, suggest these should include the extent of belief that the climate is actually changing; awareness of the type and form of change; knowledge of technology, not only today but in the years to come; and assumptions about what governmental policies will be in various regions over time.

It is theorized that there that the more Science and Technology (S\&T) interventions for climate change adaptations are developed, rural and agricultural communities would become less vulnerable to climate-related natural disasters. Adoption of sweet potato as one of the priority commodities of the Bicol Region is regarded as an adaptation strategy to the inherent vulnerability of the Region to natural hazards and climaterelated disasters. Sweet potato matches the need of the region for crops that are resilient to typhoons and other natural calamities and marginal areas, for security purposes, and as source of income and livelihood.

\section{Methodology}

This study made used a variety of social research methods such as sample survey, key informant interviews, focus group discussion and filed observation. The sampling size of this study are composed 30 respondents. About 10 key informants were interviewed to get more in-depth information about the production and post-harvest practices of the sweet potato farmers. A focus group discussion (FGD) was conducted to tackle issues emerged in the process. The respondents and key-informants considered in this study are farmers who cultivated small farm and are living in the selected upland 
communities in Albay and Camarines Sur, Philippines. One important part of the study was the actual field observation conducted by the researcher in order to validate and record indigenous production and post-harvest practices being adapted by the sweet potato farmers in the region.

\section{Finding and Discussion}

\subsection{Socio-Demographic Profile of the Respondents}

Most of the respondents interviewed were male whose ages ranged from 36-40 and 46-50 years old. Most were married and are elementary graduates. Generally, the level of education of the respondents were relatively low. Most of them were Roman Catholic and with 6-10 number of family members. The monthly income of the respondents ranged from $\mathrm{P} 1,000.00-\mathrm{P} 2,000.00(\$ 20.00-\$ 40.00)$. Most of the respondents have live in the community for 20-30 years. Most of the respondents were natives of the community. Most of them are small farm holders. The respondents came from selected upland communities in the Municipality of Buhi, Camarines Sur and Tabaco City, Albay, Philippines.

\subsection{Indigenous Knowledge and Practices in Planting Sweet Potato}

Several indigenous knowledge and practices guided the sweet potato farmers in their planting activities. Some of the common knowledge and practices are as follows: (1) they prefer to plant kamote during full moon they believe that the root crops will be bigger and healthier; (2) they do not get the vines to be used in their farm when it rains as well as they do not plant the vines when it rains too because according to them the root crops will have many fibers; (3) the best time for planting kamote when the clouds look like mounds (Columbus clouds); (4) they normally plant kamote in the morning; (5) before sunset they plant three pieces of vines after which they continue the planting the following morning; (6) before they plant the kamote vines they recite the Our Father prayer; (7) only men should do the planting of the first 3 pieces of kamote vines and he must take off his clothes and bury his testicles on the grounds where he will plant the first three pieces of kamote vines, which is usually done during the sunset a day before the actual day of planting of the kamote cuttings; (8) the one who plant the kamote should be barefooted; (9) women are not encouraged to join in the planting of kamote because they believe that when women is the one who planted the kamote the textures of the root crop are rough and it has a crack on it; (10) they also believe that the one who plant the kamote should not smile while planting so that the root crop will not have cracks; (11) the person who will plant kamote must have a full stomach; (12) for the root crop to become sweeter in taste they would put sugar on the first harvested root crop when they cook it; (13) when their farms are being attacked by pests they do the "pagtulod" ritual by offering food usually sticky rice and do the prayer in the fields and they leave the sticky rice in the fields wrapped in banana leaves; and (14) they do not plant kamote during the month of May because the word "May" when translated in Filipino is "Mayo" which means "Nothing" in Bicol. 
Each individual farmer has his/her own personal set of "Pagtubod" (beliefs) associated to place, astrological signs and "Paglihi" (use of charms). They acknowledge a common calendar of good and bad days for different farming activities. Most of them knows that they should refrain from doing planting on Mondays and they should also refrain from planting during "Palunod" (last quarter of the moon) including taboos associated with particular month-day combinations.

Most of the respondents perform planting, cultivating and harvesting of kamote based on astrological signs and moon phases. They do planting by the signs because they rely on astrological signs for planting, cultivating and harvesting primarily as guide for growing crops and other plants. Most of the respondents preferred to plant kamote during "Gimata" (new moon) or "Kabilugan" (fullmoon).

This could suggest that the informants preferentially rely on ecological knowledge when reasoning about their farming activities. Thus, these rituals which revolve around their farming/cultivation cycle are part of their worldview (cosmology) shared by and among the different groups of farmers in the Bicol Region. This knowledge spans from clearing the land, tilling, selecting seed varieties for planting, harvesting and storage, and identifying weather patterns.

Indigenous knowledge allows for practices to serve as a solution to a variety of farm problems. This indigenous knowledge was used by farmers in a number of facets including land preparation, selection of planting materials, management of soil fertility, pests and weeding control, harvest processing and postharvest management. Most sweet potato farmers used methods that have been passed on them by their ancestors through indigenous knowledge systems. Indigenous knowledge is perceived to be the knowledge that is innate to a given community or culture (Warren, 1997). It creates the basis for communal decision-making in agriculture, food preparation, food preservation, and natural resource management.

Indigenous knowledge has played important roles for farming communities in managing their livelihoods, and in continuously adapting to changes in their environment. Gaining a full understanding of these indigenous knowledge that exists in a local community is therefore a necessary to appreciate and developed the need for farmers to learn about the crop and its management, given the limited availability of scientific knowledge. Indigenous knowledge played a vital role in sweet potato farming in the Bicol Region which is continuously influenced by local creativity, innovation and experimentation.

\subsection{Land Preparation and Soil Fertility Management}

As to land preparation, sweet potato farmers first removed the grasses and then plow the area to fully haul off those grasses. They use carabao-drawn plow and plowed the soil twice to further control the growth of the grasses by removing its roots. A hoe or plow was used to prepare the areas to be planted with sweet potato. A hoe was used especially by those with limited areas to cultivate. Farmers usually formed ridges. Mounds are preferred by the respondents working entirely with hand tools. In some communities, broad raised beds are used particularly on a very wet soil. While on deep, well-drained soil, planting may be done on flat fields. The farmer respondents prepared the fields with the distance of $75 \mathrm{~cm}$ and they planted $25 \mathrm{~cm}$ to $30 \mathrm{~cm}$ kamote vines. The 
respondents made sure it is with the right length and size to have a good harvest. Moreover, some respondents plant sweet potato in ridges during the rainy season and in furrows during dry season spaced at $30 \mathrm{~cm}$ between hills.

Furthermore, most of the respondents said that the soil must not be rocky and it is the right land condition for planting sweet potato. The months of June, September, October and November were the ideal months for planting sweet potato. Aside from the carabaodrawn plow, "Asada" (Hoe) was also commonly used by the respondents in their land preparation. The respondents said they used the abovementioned tool to clean the land easily. Cleaning and removing the weeds were the proper preparation of the space before planting of the sweet potato.

The members of the family particularly the husband and wife were the ones preparing the land for planting kamote. Land preparation is predominantly performed by men. Farmers have varied processes in land preparation. They first check the quality and characteristics of the soil. Cultivation of dry or very wet soil can break the soil structure leading to poor drainage and aeration, surface crusting, cracking allowing entry of weevils, and greater susceptibility to erosion.

Generally, farmer respondents preferred "buhaghag" or sandy loam soil, black or dark grey soil (volcanic soil) and soft soil. On the other hand, as to the kind of soil, most of the respondents believe that sweet potato grows very well in sandy loam soils, exposed to sun, and reasonable amount of water and nutrients. Kamote love heat. The hotter it is, the faster its growth.

To enhance, maintain and improve the soil conditions most of the respondents made used of animal manure, chicken manure and decomposed weeds. Farmer respondents do not prefer to use commercial fertilizers because they believed it can destroy the quality of soil and their food source. Ecological factors can lead to poor yield and also include technical limitations such as poor land preparation, lack of high-yielding varieties that can adapt to different climate conditions, poor harvest management and poor postharvest management.

As to the strategies of improving the soil quality, most of the respondents said that they do not have advance or scientific knowledge on how to maintain the fertility of the soil. But when they were asked what they do in their farms they said as stated earlier they put animal manure, chicken manure, decomposed leaves; remove weeds; practice crop rotation or planting of two other crops one after the other; and some of them transfers to new areas so that the soil can rest for awhile so that the nutrients of the soil will be regained. For them to know the quality of the soil whether it is improving or diminishing or being maintained, the respondents revealed that it can be manifested on the quality of the root crops being produced. Above all, the respondents further revealed that if the root crops are healthy, it is an indicator that the soil is healthy, too.

Kamote farmers expressed reasonable knowledge on soil fertility indicators. This was mainly determined by soil characteristics, types of weeds growing in an area and crop characteristics such as yields and the general appearance of the plants. Soil types, degrees of soil fertility, and land use categories were also desegregated by farmers. Color texture and even taste usually distinguish soil types while some classified their soil on vegetative cover. 
Farmers can determine when soil is exhausted. They revealed that water retention level reduces substantially, the plants/crops or weeds are stunted and leaves become yellowish and the crop yield decline at an increasing rate. Decline in soil fertility can also determine by evident loss of crumb structure. It also becomes very light, dusty or sandy in texture. The soil color changes from dark or brown to reddish with increased number of small stones. As observed by farmers when soils are exhausted, it allows the growth of the weeds like, "bagangan", "walis-walis", "turog-turog", "turotabako", and "lila".

Soil fertility depletion has been identified as a fundamental reason for decreasing yields of sweet potato in the Bicol Region. To address soil fertility loss sweet potato farmers used various means at every stage of the planting process. This includes using animal manure, composting or rotten leaves and grass, mixing of ashes on the soil, making of mounds by collecting and heaping trash in preparation for planting sweet potato which most farmers preferably planted on raised seed bed/ridges. Also, farmers practice crop rotation to rejuvenate the soil. For them what they are doing are crucial to enhance soil fertility.

\subsection{Planting Materials and Planting Techniques}

Farmer respondents choose to give descriptive labels for their sweet potato cultivars according to various aspect of their environment. For instance, they assign names based on a distinguishing characteristic (e.g. Aga Hapon for cultivar with red leaves), the place it came from (e.g. Sinorsoganon means from the Province of Sorsogon), the person who introduced the cultivar (e.g. Bulaw), or even a popular personality (e.g. Gloria, the former President of the Philippines). There are various sweet potato cultivars that the respondents used in their farms. Their local names are: (1) Tres Colores, (2) Sinorsoganon, (3) Milagros, (4) Gloria, (5) Suraw, (6) Durat, (7) Buko-Buko, (8) Sinantol, and (9) Kinabayo.

The locally known variety of kamote tres colores were commonly planted by most of the respondents. As to the source of their planting materials, most of the respondents revealed that they bought the planting materials from others while some of them borrowed planting cultivars from their neighbors. Although, some of them preferred their own variety to be planted, so they reserved vines/cuttings from the previous planting season. Good vines and good leaves were used by the respondents in evaluating the quality of the materials to be used in planting sweet potatoes. After choosing the vines for planting, most of the respondents said that they stored the vines for two days before the actual planting. To identify bad seed (vines) from good seed (vines) the respondents said that good seed should be flowery. As to the time or period of planting sweet potato, June, September, October, and November were the best months for planting kamote. Most of the respondents said that sandy loam and fertile soil was the right soil for kamote. As to the depth of the hole, according to the respondents it should be six (6) inches deep. Most of the respondents planted sweet potato on ridges. They usually put three (3) to four (4) vines/cuttings per hill.

Indigenous knowledge about diversity of sweet potato cultivars were particularly important among farmers in the Bicol Region. Maintenance of this variety helps them to ensure that specific cultivars are available when and where famers need them. To 
achieve this, farmers knowledge is an essential resource for identifying, cultivating, utilizing and maintaining different cultivars for different purposes.

\subsection{Common Problems Experienced and Coping Mechanisms Adopted by The Sweet Potato Farmers}

The sweet potato root can be destroyed by several soil insects such as the sweet potato weevil, rootworms, white grubs, white fringed beetles and flea beetles. The sweet potato weevil larva is the only insect that tunnels throughout the root. Most of the farmer respondents revealed that there are several insects and pests that attack their crops. The most common are the "Ulalo" (Grub) "Bukbok sa kamote" (sweet potato weevil) and Apids.

To combat the worms and other insects attacking their crops, they said that they do not use artificial chemicals because artificial pesticides are not suitable for sweet potato. To repel insects in their farms, the respondents said that they plant "rosasito" (marigold), "tanglad" (lemongrass), "sibuyas" (onions), "madre de cacao", and "tagbak" in their farms. Farmers plant these plants because they believe the scent produced by the plants repels pests. Apids were one of the commonly observed sweet potato pests. Respondents controlled it by cutting the infested leaves and burying them.

While some of the respondents do make smoke and fire by burning dried leaves late afternoon nearby in their farm so that the insect will be attracted to the lights and eventually be burnt, they also burned dried grasses at the direction where the air is coming so that the smoke will go to the field to drive away the pests. The respondents also said that they arranged their crops in a special manner to control weeds and insects. They also said that farm area should always be clean so that rats will not stay in the area.

Further, they also did the "paghapag"- offering of sticky rice and other foods and do rituals like reciting the prayer in the fields, because they believed that sometimes, pests and other problems in their farm were brought by the spirits they disturbed. Local kamote farmers demonstrate respect for the supernatural. Along with other problems experienced by sweet potato farmers in their farms were the presence of different weeds, the common weeds growing and spreading in their farms are the "Bagangan", "Walis-Walis", "Turog-Turog", "Turotabako", and "Lila". To prevent and minimize weed spread and competition with crops respondents identified various practices they undertake during weeding. These practices include early planting and crop rotation, intercropping, timing and placement of manure and ashes. They also used mechanical weed control methods which involved hand-hoe weeding.

These indigenous knowledge on pest and weeding management strategies are based on "built-in features" in cropping systems such as farm location, crop rotation and intercropping, or on specific responsive actions to reduce pest attack such as timing of weeding, use of plants with repellent or insecticide actions. Though the respondents experienced some problems with the insects and pests attacking their farm, they did not lose hope to plant sweet potatoes. As can be gleaned from the data, the respondents find their own ways to combat and control the insects and other pests in their farms. They used their indigenous knowledge to save money and have good harvest. Above all, they are convinced that their strategies were viable and ecologically friendly. 


\subsection{Post-Harvest Management of Sweet Potato}

Sweet potato the versatile crop has multifarious uses. It is not only grown as food substitute for rice and corn but also as a potential source of raw materials for industrial uses and food delicacies. Sweet potato is being processed as feeds, flour, starch, and pectin for local and export markets. The flour is further processed into fermented products such as soy sauce and alcohol. While sweet potato has increasing in importance globally, there seems to be a relative dearth and paucity of information on the efficacy of local indigenous techniques of preserving the crop.

As revealed by the respondents, the sweet potato root crops were commonly used for households and community as ingredients for delicacies like kamote cue, kamote fries, "kalingking", jam, and preserves are among the common products local residents prepare or produce. On the other hand, as expressed by some of the respondents if they have over supply of kamote root crops they also make kamote flour being used for breads, cookies, and noodles. Decisions related to utilization and processing of sweet potato root crops were generally carried by the women.

As to portion of kamote that was being sold, most of the respondents said that big portion of the harvest were being sold in the market or the wholesaler/buyer who comes to their community. The couples are the one who classify the crops they were going to sell and to be consumed as said by most the respondents. The respondents revealed that they are the ones who decide for the portion of the harvested root crops to be sold and reserved for their consumption. For choosing the crops to be consumed by the family, the couples are the one who handle the selection. Most of the respondents said that their harvested root crops are being brought to the market for selling. As to who are in-charge of selling of the root crops, most of the respondents made known that it is the wife who sells it to the market. Women were in charge of marketing. Decisions related to this activity were dominated by the women.

In line with the preservation of the root crops allocated for household consumption for longer life span they keep it in a dry place in their kitchen while others revealed that they buried the root crops under the soil or ash for four (4) to six (6) months. Also, it is critical to ensure that the stored kamote root crops does not have any bruises as this will aid in infection and rotting. The process of preserving the root crops were predominantly managed by the women.

The absence of suitable storage facilities among sweet potato farmers continues to expose them to food insecurity. Therefore, sweet potato farmers are thus making use of locally available preservation methods adopted from their descendant's indigenous knowledge to improve storability of sweet potato. Sweet potato farmers rely on the existing methods on sweet potato preservation based on their indigenous knowledge. This is so because the advance approaches based on laboratory process are relatively expensive.

\subsection{Gender Division in Sweet Potato Farming}

While sweet potato farming is considered by most of the respondents as a family activity they have denied that there is a specific job assigned to a particular person. Farming and decision-making were carried out by women and men in sweet potato cultivation, production, processing, utilization and post-harvest management. There 
were particular activities which women were involved in and their decisions were given weight. They have set gender division of labor in the sweet potato production, as to role of women, most of the respondents answered that women are in charge of weeding, harvesting the root crop, and marketing of the root crop, since according to them the women were the ones who do the budgeting in the family. According to them, women have no unique knowledge in the production and cultivation of sweet potato. Though there are some prohibitions observed, like women are not encourage to plant kamote believing that the produce will not be good. Women also are being prohibited to visits the farm once they have their monthly period (menstruation) believing that once the woman visit the farm it would cause destruction to the plant. On the other hand, as to the role of men in the sweet potato farming the respondents answered that the men are in charge of the heavy works in the fields like the plowing of the fields, making the small mounds, gathering of planting materials like the vines and the needed materials for their rituals, the planting of the kamote vines. Decisions related to planting, especially on the variety used, time of planting, and scheduling of planting dates were mostly done by men. Men also made decisions to intercrop and replant the field immediately after harvesting. Generally, men have many roles being performed in the cultivation and production of sweet potato.

Harvesting was mostly done by women. Each hill was dug with care during harvesting. This is the reason revealed by the respondents as to why the women usually did this task. Besides most of the respondents considered this task as "light and easy". Decisions related to harvesting, processing, utilization and marketing were generally carried by women.

The women in the Bicol Region, Philippines have no unique gender role being performed in the cultivation and production of sweet potato. Moreover, gender biases and discriminations were observed based on the roles assigned to them. However, their role was more on marketing as a customary representation as maintained based of their cultural backgrounds and practices.

Women play a crucial role in the sweet potato farming and their participation should be valued. It is important to identify and highlight the undertakings and contributions of women in the sweet potato production, processing and utilization. Knowledge and information on their contributions could lead to technology generation and utilization of sweet potato and other root crops grown in the region (Pascual, Abamo, and Binongo, 1989).

\subsection{Discovering the Science Behind the Indigenous Knowledge}

This study was conceptualized on the premise that as human beings try to adapt to the environment that he/she lives and derives his/her livelihood, he/she improves his/her knowledge, skills, and strategies to enhance/harness natural resources in a sustainable manner. The knowledge and skills are derived from his/her daily interaction with the environment, through observations, experiments and contacts with others. They greatly shape and define the decisions they have made regarding resource utilization. These knowledge, skills, and practices relating to natural world and resources were handed down to them through the cultural learning process. 
It is difficult to disentangle the influences of ecology and culture on coexistence thinking. Culturally, humans learned causal rules on how they adapt to environmental challenges. The process by which people incorporate observations on biological processes into natural resource management and their worldview is known as the corpus-praxis-cosmos ("knowledge-practice-belief") in ethnoecology (Berkes et.al. 2000, Barrera-Bassols and Toledo, 2005). The corpus or knowledge includes people's observations on climate, soils, plants, animals and vegetation which may be gained individually or collectively over generations. Praxis or practice encompasses activities that use the body of environmental knowledge to harness resources, that includes agriculture, horticulture, hunting, fishing, agroforestry, livestock and resource extraction. Cosmos or belief includes culturally important concepts and constructs such as sacred spaces, rituals, myths, and elements of the belief systems and moral codes. The three domain overlap and at their center lies the "ethnoscape" which views landscape as a socio-cultural construct rather than a purely biophysical one (BarreraBassols and Toledo, 2005). The sweet potato farmers use this framework with recognition that local environmental knowledge reaches beyond simply identifying or labelling particular features. Indigenous knowledge are embedded in the social, cultural and moral milieu of their particular community. In other words, their actions or thoughts are perceived to have social, cultural and cosmological implications.

Indigenous knowledge is gained by farmers and other resource users based on interactions with their environment, society, and culture overtime. It generally emerges from people's direct experiences as they learn deliberately or by chance about their biophysical and socio-cultural environments. It may include knowledge handed down from previous generations, shared by other communities, and acquired from external contacts. Further, this indigenous knowledge has historically served as an important resource for farming communities in managing their livelihood, natural resources and in continuously adapting to changes in their environment.

For a long period of time, kamote farmers in the Bicol Region have planned their production, conserved natural resources by adapting indigenous knowledge. The development of indigenous knowledge systems, including management of natural environment, has been a matter of survival to the people who generated these systems. Such systems are cumulative, representing generations of experiences, careful observations and trial and error experiments Louise, 1998).

These systematic body of knowledge acquired by local farmers through accumulation of experiences and informal experiments of their environment made them knowledgeable about their own situations, their resources, what works, and what doesn't work and how one change impacts other parts of their systems. Indigenous knowledge is dynamic and it changes through creativity and innovativeness as well as through contact with other local knowledge systems.

What is clear from all of these perspectives is that for a very long period of time, kamote farmers in the Bicol Region are knowledgeable about their resources and the environment in so far these guide/govern their farming practices and cultural heritage. It involves the evolution of perceptions, beliefs, and facts through experiences, inherited sources, natural experiments and very familiar understanding of their environment. These results into cultural practices, norms, and values they owned. When these are used and passed on to the next generation, it becomes a belief system. 
According to World Bank, indigenous knowledge has an important role in global knowledge economy. It encompasses the skills, experiences and insights of people, applied to maintain or improve their livelihood. Indigenous knowledge is developed and adapted continuously to gradually changing environments and passed on from generation to generation, closely interwoven with people's cultural values. The same indigenous knowledge is also the social capital of the poor, their main asset to invest in the struggle for survival, to produce food, to provide shelter or achieve control of their own lives (World Bank, 1997).

\section{Concluding Remarks}

The study documented the indigenous knowledge and practices planting sweet potato in the Bicol Region, Philippines including land preparation, soil fertility management, pest management, post-harvest management and processing, and gender division in sweet potato farming.

Indigenous knowledge has historically served as an important resource for farming communities in managing their livelihood and in continuously adapting to changes in their environment. It generally emerges from people's direct experiences as they learn deliberately or by chance about their biophysical and social environments. It may also include knowledge handed down to them from previous generations, shared by other communities, and acquired from external research institutions. Thus, it forms a body of knowledge that usually extends beyond the indigenous, traditional and technical. Since it is shaped by particular social, cultural, physical and temporal contexts, local knowledge is inherently diverse. This paper expounded on the role that indigenous knowledge plays in the cultivation, production, and post-harvest management of sweet potato.

The contribution of indigenous knowledge and practices to the sweet potato farmers cannot be underestimated in terms of enhancing the household and community food production and food security particularly in the upland rural areas of the Bicol Region. The indigenous knowledge of the people is very effective in meeting their food requirements, and effective in areas of land preparation, soil fertility enrichment, planting, pests management and weeding, harvesting and post-harvest management. Thus, the existing research on indigenous knowledge and household food security in the Bicol Region has not documented some issues on the contribution of indigenous knowledge and practices to food production and food security, including socioeconomic factors that determine the use of indigenous knowledge and practices, including how farmers perceive the effect and their preference of the practices, and which of the practices hold a significant effect on enhancing household and community food production and food security.

There is much to be learned from the IK systems of Kamote farmers in the Bicol Region. If we are to move towards interactive technology development beyond the conventional transfer of technology approach, it is feasible, efficient, and cost effective to learn from the local specialists/experts.

While many studies documented and demonstrated the use of indigenous knowledge and its crucial role to the attainment of sustainable development, food security and reversing development problems like environmental degradation, there seems to be a 
consensus in the need for continuous documentation of indigenous knowledge in the country. The indigenous knowledge needs to be continually identified and revisited, as it is not static but continuously adapting to respond on ecological and socio-cultural changes in the community. Many of these indigenous knowledge have been lost through death of elderly people since there was no formal documentation of such knowledge. Some individuals deliberately refused to share the knowledge they know and possess to others because of selfishness and the desire to control and avoid competitors.

It is therefore being recommended by this study for future researchers to explore other aspects of indigenous knowledge particularly on like people's application of coexistence to subsistence through intercultural approach by contrasting samples from different places/region/country.

\section{References}

Atteh, O.D. (1980). Resource and Decisions. Peasant Farmer Agriculture Management and its Relevance for Rural Development Planning in Kwata, Nigeria.

Baldos, J. M. 2009. Sweet Potato Production, Livelihood Program Undertaken in Tarlac, Albay. In Agri Business Week. Posted on November 1, 2009. http://www.agribusinessweek.com/about/

Barcia, R. M. Albay seeks to become to camote exporter. In: The Manila Times, December 11,2010. http://www.highbeam.com/doc/1P3-2212384961.html\#mlt

Barrera-Bassols, N.,and V.M. Toledo.(2005). Ethnoecology of the Yucatic Maya: Symbolism, Knowledge and Management of Natural Resources. Journal of Latin American Geography.

Berkes, F., J. Colding, and C. Folke. (2000). Rediscovery of Traditional Ecological Knowledge as Adaptive Management. Ecological Applications.

Bourke, R. M. 1985. Sweet Potato (Ipomoea batatas) Production and Research in Papua New Guinea. Journal of Agriculture, Forestry, and Fisheries, Papua New Guinea. The importance of local knowledge in conserving crop diversity. SciDevNet.

Edmond, J. B. and G. R. Ammerman. 1978. Cooperative Studies on the Effects of Height of Ridge, Nitrogen Supply, and Time of Harvest on Yield and Flesh Color of the Puerto Rico Sweet Potato. US Department of Agriculture, Washington.

Ikemoto, S. 1971. Studies on the Direct Planting of Sweet Potato. Chugoku National Agricultural Experimental Station.

Hahn, S. K. and Hozyo, Y. 1984. Sweet Potato. In the Physiology of Tropical Field Crops, Goldworthy, P. R. and N.M. Fisher (eds.). John Wiley, Chichester.

Kay, D.E. 1973. Crop and Product Digest: Root crops. Tropical Product Institute, London.

Kurukulasuriya, P. and S. Rosenthal. 2003. Climate Change and Agriculture: A Review of Impacts and Adaptations. World Bank, Washington. Farmers. SEAMEOSEARCA, College, Laguna, the Philippines. 
Mackay, K. T., Palomar, M.K. and Sanico, R.T. 1989. Sweet Potato Research and Development for Small

Mendelson, R. 2001. Measuring the Effect of Climate Change on Developing Country Agriculture. Paper prepared for the Food and Agriculture Organization.

Ministry of Agriculture and Rural Development. 2010. Commercial and High Quality Cultivars of Root and Tubers Crops for Processing Purpose in the Northern and Central

Vietnam. http://www.card.com.vn/news/Projects/008VIEO7/MS3 1st $\% 206 \% 20 \mathrm{mth} \% 20 \mathrm{rep}$ ort.pdf.

Nasol, R.M. 2010. Albay pins hope on camote potential. In Bicol Mail, Vol. XXVII, No. 27, December http://www.bicolmail.com/issue/2010/dec16/xpins.html.

Onwueme, I. C. 1978. The Tropical Tuber Crops: Yam, Cassava, Sweet Potato, and Cocoyams. John Wiley and Sons, New York.

Peters, J. 2001. Local Human-Sweet Potato-Pig Systems Characterization and Research in Irian Jaya, Indonesia: With Limited Reference to Papua New Guinea, International Potato Center.

Principe, K.K.S. 2016. Sweet Potato Roundtable Discussion Addresses Industry Gaps. DOST-PCAARRD, S\&T Media Service.

Purseglove, J. W. 1972. Tropical Crops: Dicotyledones. Longman, London.

Schneider, S. H. W. E. Easterling, and L. O. Meams 2000. Adaptation: Sensitivity to Natural Variability, Agent Assumptions, and Dynamic Climate Changes. In Climate Change 45 (1):203-221.

Rajasekaran, B. (1993). A Framework for Incorporating Indigenous Knowledge System into Agricultural Research and Extension Organizations for Sustainable Agricultural Development in India. Ph.D. Dissertation, IOWA State University, Ames, Iowa.

Ramirez, P. 2005. Cultivation, Harvesting and Storage of Sweet Potato Products. Vida Agricola.

Republic of the Philippines, Department of Agriculture, Bureau of Agricultural Research, 2018. http://www.bar.gov.ph.

Shanmugavelu, K. G. S. Thamburaj, A. Shanmugam, and N. Gopalaswamy. 1972. Effect of Time Planting and Type of Planting Material on the Yield of Sweet Potato (Ipomoea batatas). South India Horticulture.

Ton, C. S. and T.P. Hernandez. 1978. Wet Soil Stress Effect on Sweet Potato. In: Journal of American Society of Horticultural Science.

Warren, D.M. (1996). Indigenous Knowledge, Biodiversity Conservation and Development in the Third World Countries. 
Warren, D.M.(1993).The Role Indigenous Knowledge in Facilitating the Agricultural Extension Process. Paper presented at International Workshop on Agricultural Knowledge Systems and the Role of Extension, Germany.

Warren, D.M.(1987). LINKING Scientific and Indigenous Agricultural Systems; J.L. Compton (ed.), The Transformation of International Agricultural Research and Development. Boulder: Lynne Rienner Publishers, Boulder, USA.

Watanabe, K. K. Ozaki, and T. Yashiki. (1968). Effect of Soil Physical Conditions on the Growth and Yield of Crop Plants and Soil Air Composition and Soil Bulk Density on the Growth of Sweet Potato. In: Proceedings of Crop Science Society Japan.

Wilson, L. A. (1982). Tuberization in Sweet Potato (Ipomoea batatas). In: Proceedings of the First International Sweet Potato Symposium, AVRDC, Tainan, Taiwan.

World Bank (1997). World Bank, Knowledge and Learning Center. Indigenous Knowledge for Development A Framework for Action. Unpublished Report. 